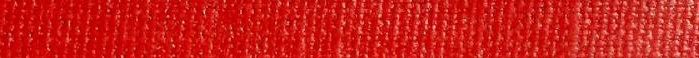

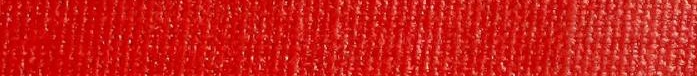

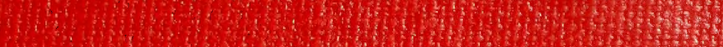

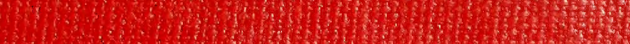
(1) (

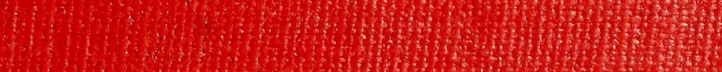

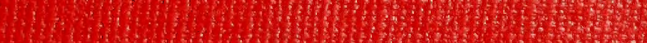

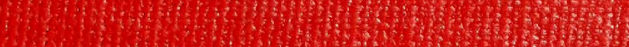

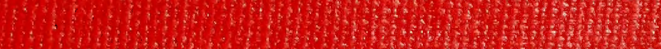

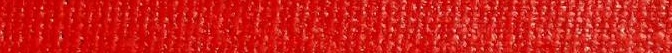

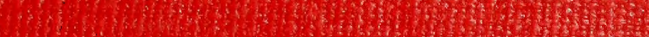

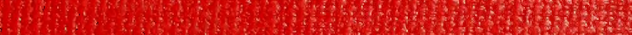
H. 1.

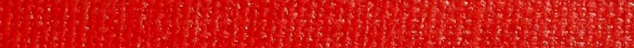
4.

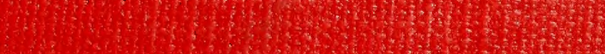

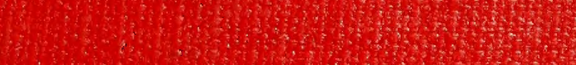

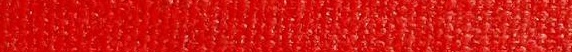
1.6. 20.9.2.

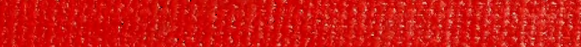

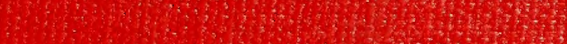
1/ 402.

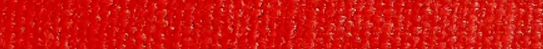

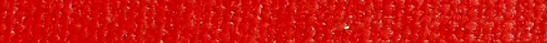
4.:

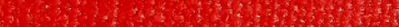
2.

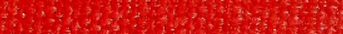
6. 3. (2)

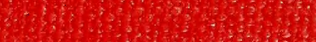

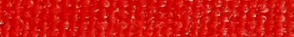

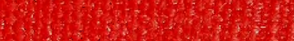
W.

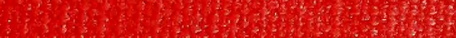

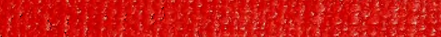

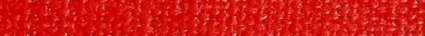

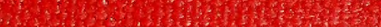

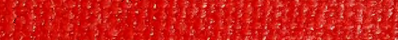
73.

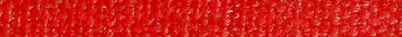

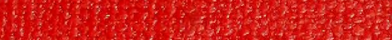

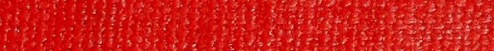

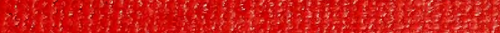

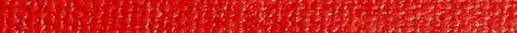

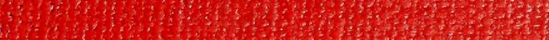
3. 4 (1) (1)

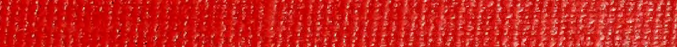
(1)

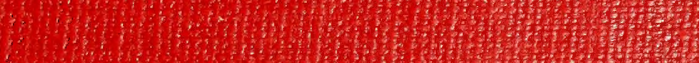

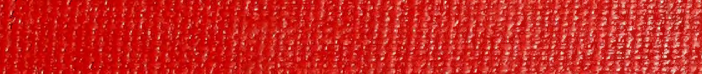
- 5 (1)

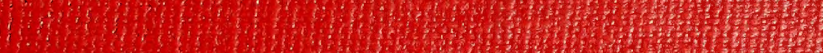

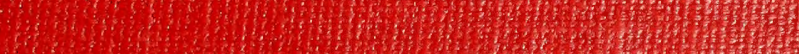

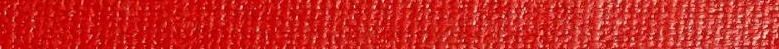

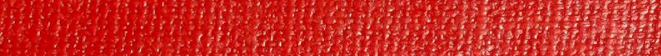
s.

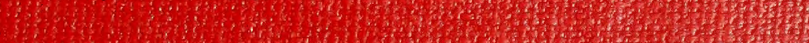

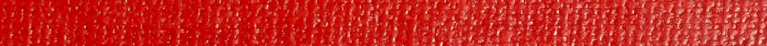

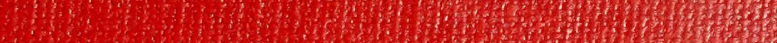

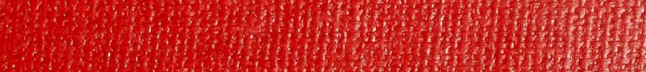




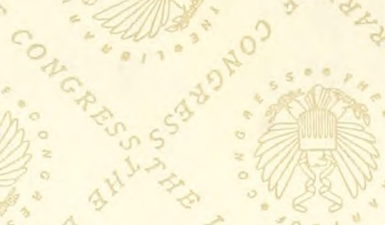

(a)

की

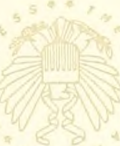

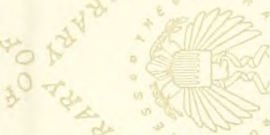

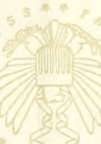

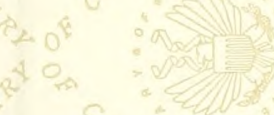

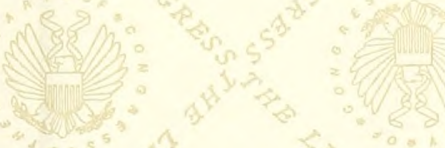
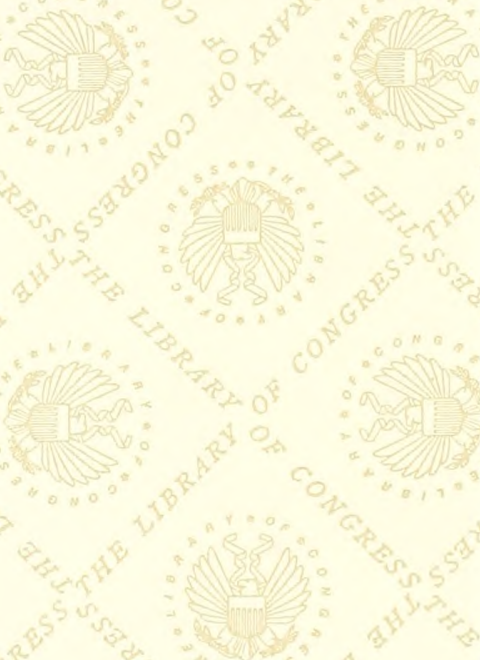

$-0^{2}$

(2) 0

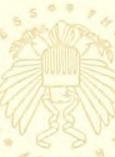

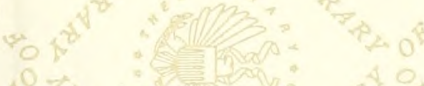

$30 \%$ का if

$\frac{1}{25}$

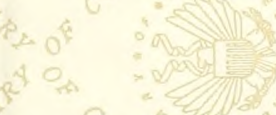

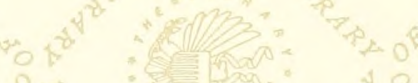
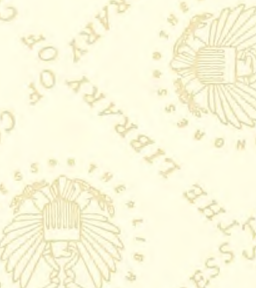

:

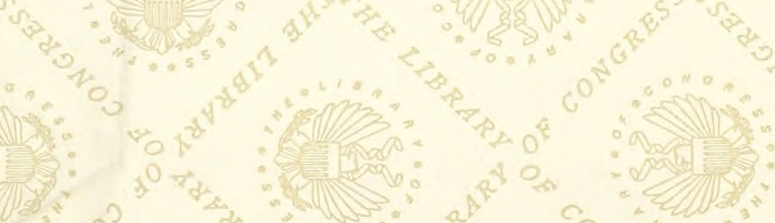

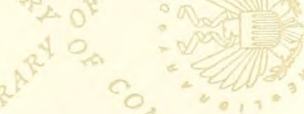

(ivi)

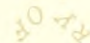





$\left.\begin{array}{c}62 \mathrm{D} \text { Congress, } \\ 2 d \text { Sesion. }\end{array}\right\}$ HOUSE OF REPRESENTATIVES. $\left\{\begin{array}{l}\text { REPorT } \\ \text { No. } 546 .\end{array}\right.$

\section{ESTABLISHMENT OF AGRICULTURAL EXTENSION DEPARTMENTS.}

ApriL 13, 1912.-Committed to the Committee of the Whole House on the state of the Union and ordered to be printed.

Mr. Lever, from the Committee on Agriculture, submitted the following

\section{R E P O R T.}

[To accompany H. R. 22871.]

The Committee on Agriculture, to whom was referred the bill (H. R. 22871) to establish agricultural extension departments in connection with agricultural colleges in the several States receiving the benefits of an act of Congress approved July 2, 1862, and of acts supplementary thereto, having considered the same, beg to report it back to the House with amendments and with the unanimous recommendation that the bill as amended do pass.

The object of the bill is to establish agricultural extension departments under the direction of the land-grant colleges of the several States to aid in carrying to the people useful and practical information on subjects relating to agriculture and home economics through field instruction, demonstrations, publications, and otherwise.

The Federal Government has committed itself emphatically and irrevocably to the policy of appropriating money to aid in the encouragement, development, and preservation of agriculture, both in the maintenance of its most eificient Department of Agriculture and through a series of legislative enactments endowing agricultural colleges and establishing agricultural experiment stations in the several States. Thus agriculture has been recognized as of supreme importance to the Nation, and is so recognized by every thoughtful student of present economic conditions.

Liberal as we have been toward our agriculture, the fact remains that this Government expends less money for its encouragement and development, in proportion to its population and the extent of its agricultural area, than any nation of Europe, with the possible exception of Spain. It was recently pointed out, in a reliable farm journal, that less than 1 per cent of the annual total appropriations of the Government is expended for purposes of aiding agriculture - a most significant statement when agriculture is unquestionably the basic 
industry upon which is builded every other industry and upon which is dependent the real prosperity of the Nation.

The enactment of the first Morrill Act, "for the endowment, support, and maintenance of at least one college where the leading object shall be **** to teach such branches of learning as are related to agriculture and the mechanic arts," was epochal, being the first serious national effort to aid agriculture in a practical way. As a result of this encouragement and Federal recognition, every State has a well-equipped agricultural and mechanical college, training its young men to solve agricultural and industrial problems.

It was soon discovered that their peculiar difficulty lay in a lack of sufficient, definite, and exact scientific information. Realization of this insufficiency became so manifest and so insistent that the Hatch Act, establishing agricultural experiment stations, "to promote scientific investigation and experiment, respecting the principles and applications of agricultural science," was enacted 25 years after the land-grant colleges were authorized. Under this act agricultural experiment stations, devoting their energies to gathering scientific truths and exploding harmful fallacies touching agriculture, have been established in each of the States.

Subsequent legislation has been confined to the enlargement of the funds for the furtherance of the fundamental ideas involved in the original Morrill and Hatch Acts, since the enactment of which the Federal Government has expended $\$ 67,000,000$ upon these institutions, as follows:

Statement showing the amount of money that has been expended by the Federal Government for State experiment stations and agricultural colleges.

STATE EXPERIMENT STATIONS.

Total amount expended under the Hatch Act from 1888 to June 30,

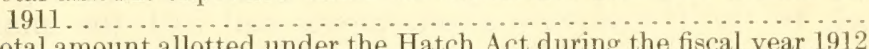
Total amount allotted under the Hatch Act during the fiscal year 1912
up to and including the quarter ending Mar. 30, $1912 \ldots . . . .$.

$\$ 16,807,338.94$

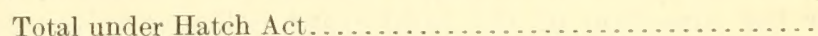

Total amount expended under the Adams Act from 1906 to June 30,

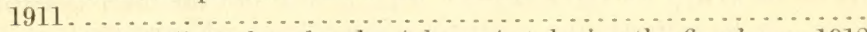

Total amount allotted under the Adams Act during the fiscal year 1912 up to and including the quarter ending Mar. 30, 1912..........

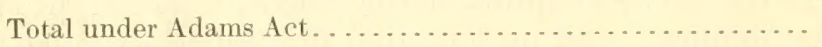

Total for State experiment stations under both acts.........

$540,000.00$

$17,347,338.94$

$2,828,665,21$

$540,000.00$

$3,368,665.21$

$20,716,004.15$

STATE AGRICULTURAL COLLEGES.

Total amount paid from 1890 to 1912, inclusive, under the acts of Aug.

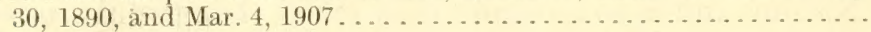

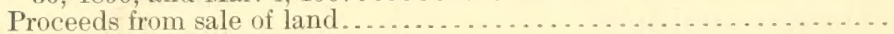

Value of unsold land (estimated) . . . . . . . . . . . . . . . . .

Total for agricultural colleges under both acts, etc . . . . . 47, 192, 429.00 RECAPITULATION

Total for State experiment stations.

$20,716,004.15$

Total for agricultural colleges.

$28.802,000.00$

$13,348,041.00$

$5,042,388.00$

Grand total.

$67,908,433.15$ 
When it is remembered that only a very small per cent of the people can enjoy the direct benefits of these institutions, it is evident that the system of Federal aid to agriculture is yet incomplete. "The colleges deal with ideas; the stations with facts. The colleges teach theories of agriculture; the stations prove good theories and disprove poor ones." The stations gather facts of a practical and scientific nature; the colleges disseminate these facts, but only to limited numbers in proportion to the total rural population.

Your committee believes that this bill is the next logical, necessary step to give this country the most comprehensive system of governmental aid to agriculture in the world. The central idea of the bill is to bring to the farmer, upon the farm, this information, these scientific truths, and these better methods of agriculture which the colleges and stations have been and are gathering. Past legislation has resulted in the accumulation of valuable agricultural information; this bill proposes to disseminate it in the most practical and far-reaching manner.

Objection can not be urged to the bill on the theory that it proposes to commit the Government to a new and untried policy. It seeks only to give fuller force and more complete effect to the agencies already created by congressional action. Thirty-four of the States are now supporting, through their agricultural colleges, some kind of agricultural extension departments; but, as urged before the committee, the moral effect of the aid of the Federal Government upon this line of work will be of incalculable value in further extending and promoting it.

The bill has received the most emphatic indorsement of the leading agricultural thinkers of the country, the rural press, influential business associations, agricultural organizations, and is explicitly commended by President Taft in his address at the Kansas City Conservation Congress, in this language:

The welfare of the people is so dependent on improved agricultural conditions that it seems wise to use the welfare clause of the Constitution to authorize the expenditure of money for imprevement in agricultural education and leave to the States and private enterprise general and other vocational education. The attitude of the Government in all this matter must be merely advisory.

It is now proposed to organize a force of 3,000 men, one to every county in the United States, who will conduct experiments within the county for the edification and education of the present farmers and of the young embryo farmers who are being educated. It is proposed that these men shall be partly paid by the county, partly by the State, and partly by the Federal Government; and it is hoped that the actual demonstration on the farms in the county - not agricultural stations or schools somewhere in the State-but in the county itself, shall bring home to the farmers what is possible to do with the very soil that they themselves are engaged upon.

The principle of agricultural extension work, through field instruction and demonstrations, is recognized by every leading country of Europe, including the British Empire, Austria, Bulgaria, Denmark, France, Hungary, Italy, Holland, Germany, Russia, and Belgium.

It is a significant fact that 25 years ago the agriculture of Belgium was in a most deplorable and discouraging condition. The wise men of the nation, seeking a remedy for this situation, established a system of extension work in agriculture, such as is proposed in this bill, which in this brief period has completely revolutionized this foundation of all industries and governments, and has placed Belgium in the front rank of agricultural nations. The committee desires to submit the following brief authentic table, showing the remarkable results 
obtained only through the influence of this work of teaching the adult rural population of Belgium:

\begin{tabular}{|c|c|c|c|}
\hline Crop. & $1880-1885$ & $1907-1910$ & Increase. \\
\hline 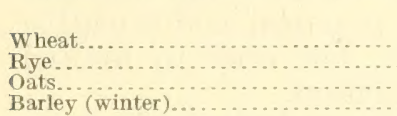 & $\begin{array}{r}\text { Bushels. } \\
24.54 \\
23.86 \\
49.79 \\
38.25\end{array}$ & $\begin{array}{r}\text { Bushels. } \\
38.55 \\
36.69 \\
81.48 \\
57.57\end{array}$ & $\begin{array}{r}\text { Bushels. } \\
14.01 \\
12.73 \\
31.69 \\
19.32\end{array}$ \\
\hline
\end{tabular}

It is likewise significant, as pointed out by authorities in agriculture, that the farmers of Europe are producing two and one-half to three times as much per acre as American farmers, and this in the face of the fact that the European lands have been under cultivation for many centuries and were perhaps originally not so fertile as ours.

Fortunately the conditions of Belgium, before the establishment of agricultural extension departments, as yet have not come entirely upon our country, but your committee is not unmindful of the striking similarity in tendencies. Soil fertility is undeniably decreasing, especially in the older States, and production is failing to keep pace with the demands of the nonagricultural classes. At the present ratio the time is not far in the future when we shall cease to produce sufficient foodstuffs with which to supply the Nation. It becomes the imperative duty of Congress to check these tendencies which, if permitted to continue, must bring about a deplorable condition. Your committee recommends this bill as furnishing a remedy with which to avoid these inevitable consequences - a remedy found allsufficient in Belgium and other European countries and which is not entirely untried in this country.

Some years ago the ravages of the cotton-boll weevil in Texas attracted the attention of the Nation, and Congress appropriated liberally to the effort to stamp it out. The necessity for a vigorous campaign to save the cotton crop of the South resulted in the formation of the farmers' cooperative demonstration work in 1904, organized by and under the direction of the late Dr. Seaman A. Knapp. The salient features of this system are:

First, the personal contact of the instructor with the farmers receiving instructions; secondly, the participation of the farmer receiving instruction in the actual demonstration of the leseon to be taught; thirdly, the certainty of success under normal conditions of the method advocated. From a small beginning, with but few trained men in the field, it has grown, developed, and been systematized into a great movement for the wide dissemination of agricultural knowledge for the man, the wife, the boy, and the girl on the farm. *** To-day it is directly instructing practically 100,000 farmers, 75,000 farmers' boys, and 25,000 farmers' girls. The farmers are divided into two classes - the one class called the "demonstrators," whose farms are actually visited by an agent once in every 30 days during the crop-growing season, or practically 8 to 10 times each year, and even more; the other, called "cooperators," are grouped around about the farm of the demonstrator, and are called together upon it for the purpose of coming into contact with the agent and receiving personal instruction. * * * Briefly stated, it seeks to press home such lessons as the better drainage of the soil, the deeper and more thorough preparation of soil for planting, the value of better seed, how to produce it, how to select it and keep it pure, the testing of seed before planting, the proper spacing of plants to suit the plant, soil, and climate, the value of intensive cultivation during the growing season for conservation of moisture, the importance of humus in the soil, and the use of barnyard manure, farm refuse, and commercial fertilizers, the value of crop rotation and winter cover crops on southern farms, for maintenance and building up of fertility, the use of more horse power and less hand power, and the accomplishment of more work in a day, the use of better tools for the same purpose, the great importance of live stock as a part of the permanent 
system of agriculture, the production of all home supplies of food required for men and animals on the farm, and the keeping of an account in order to know whence the profits and whence the loss in the farm operations.

The foregoing is an outline of the work as given by Dr. Bradford Knapp in a recent address. Your committee is informed and believes that this system of bringing home to the actual farmer upon his actual farm the best methods of agriculture is working a revolution in the agriculture of the South. The proposed legislation intends to do this same kind of work on a bigrer, broader, and better scale, under the direction of State rather than Federal authorities,

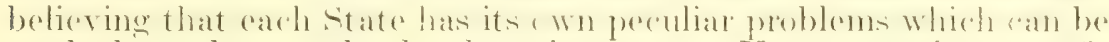
worked out best under loeal enviromment. Your eommittee confi-

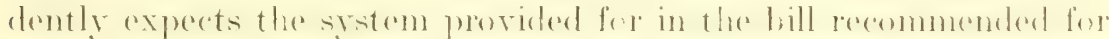
your favorable consideration to do for the whele countro , in a larger measure, what has been accomplished for the South in a smaller way under the farmers' cooperative demonstration work.

Your committee submits for the information of the House the following brief analysis of the bill by sections:

Section 1 authorizes that agricultural extension departments may

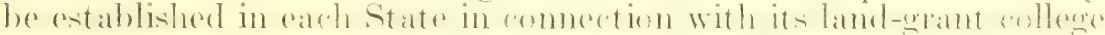
or colleges and permits the state in which two or more such colleges have been or shall be established to designate which mar administer the funds.

Section 2 defines the object and duty of these agricultural extension departments to be to give instruction and practical demonstrations in agriculture and home economies through field demonstrations, publications, and otherwise.

Section 3 makes frankable printed matter and correspondence for the furtherance of the purpeses of the act, issued from the agricultural colleges or by agents of the extension departments thereef. This privilege is meresistry in order that the plan ef the hill mas be executed.

Section 4 is the appropriating section of the bill and provides that a sum of $\$ 10,000$ shall be appropriated ammually to each state which shall assent to the provisions of the act. 'This ammul appropriation is a straight, unconditional appropriation to the several States, and amounts each year to a charge upon the Treasury of $\$+\$ 0,000$. The additional sum of $\$ 300,000$ is appropriated for the fiscal rear 1914 and an ammual increase of this appropriation of $\$ 300,000$ a jear, over the preceding year, for a period of nine years is provided until the total amount of additional appropriations will be the sum of $\$ 3,000,000$ annually. But these additional appropriations, or this sum of $\$ 3,000,000$ annually, is to be allotted among the several states in the proportion which their rural population bears to the total rural population of the United States, as determined by the next precoding Federal census. The Census Bureau defines as "urban population that residing in cities and other incorporated places of 2,500 inhabitants or more, including the New England towns of that population." 'The bill provides a sum of $\$ 10,000$ per yoar to carlestate monconditionally. and provides also that no State is to be entitled to any part of its allotment of the additional sums until its legislature has provided for the establishment of agricultural extension departments, as provided in section 1 of this bill, and it requires further that no State shall receive of these additional appropriations a sum exceeding the sum appropriated by its legislature for that year for this purpose, or 
provided by State, county, college, or local authority. The idea is that there nust he furnished to these extension departments by some authority other than the Federal authority as much as is provided by the Federal Government-no more and no less.

For example, the allotment to a given State might be the sum of s50,000, which the state would receive if it should duplicate this amount, but it might happen that the state would desire to appropriate for such a purpose only $\$ 25,000$, in which erent such state would he ontitled only to 525,500 of the Federal funds in addition to the $\$ 10,000$ which is given each year uncomditionally. The committe submits a table showing the total population of the Cuited States by sitates and the total rural populaten by sitates, and the amomint if these additional sums to which cach state will be ent itled under the basis of allotment as provided in the bill when the act shall mature at the end of 10 years, to which must be added for each State the sum of $\$ 10,000$ unconditionally appropriated.

The table is as follows:

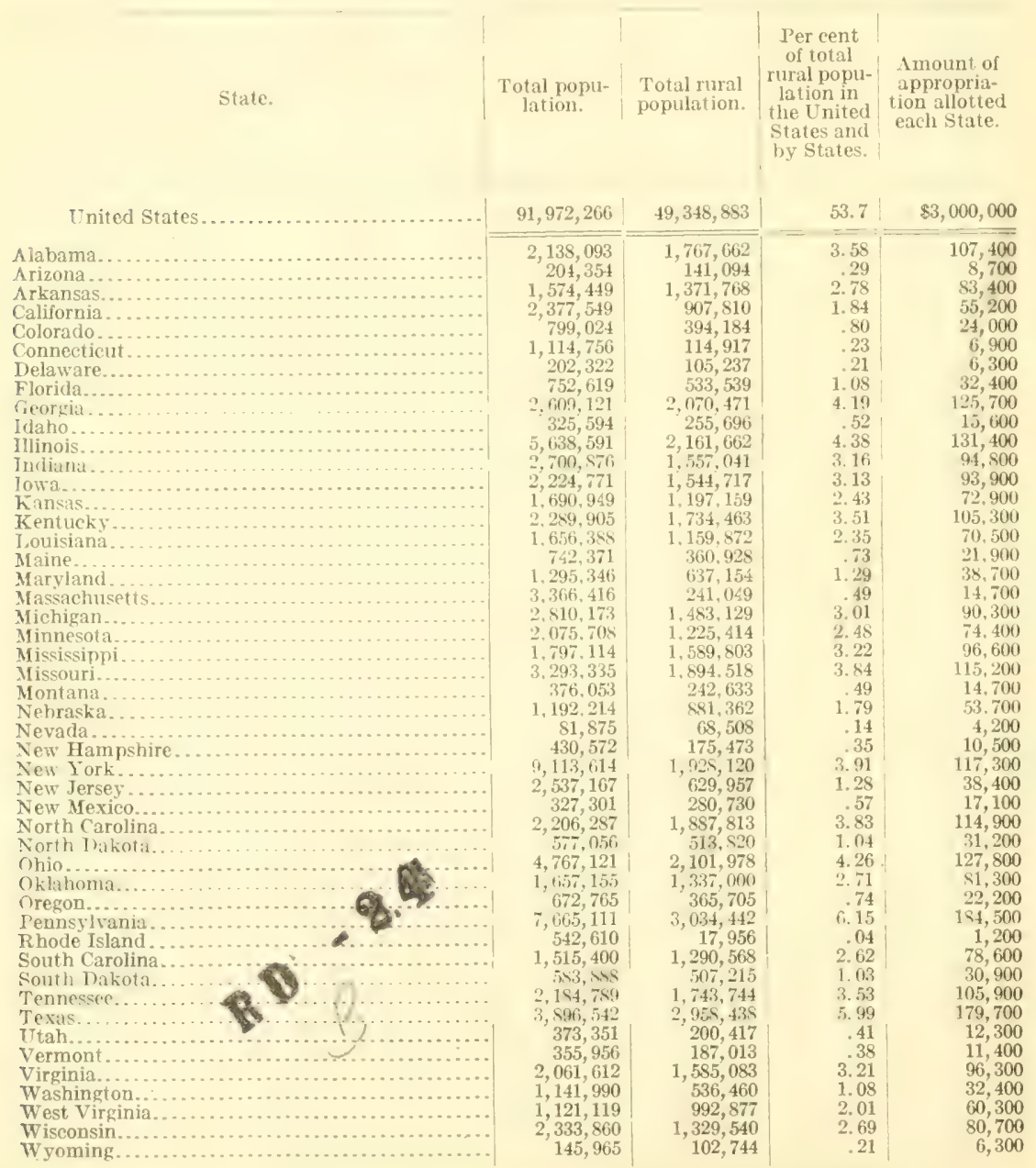


It made mandatory that not less than 75 per cent of all moneys available under this aret shall be expended each rear for fiedel instruetion and demonstrations. 'The remainder of the money is available for extension work proper, home economics, and allied subjects.

The remaining sections, $5,6,7,8,9$, and 10 , deal largely with the administrative leatures of the bill and follow closely the administrative features of the Hatch and Adams Acts.

The commit tee recommends the following amendments:

On page 2, line 7, after the word "two," insert the words "or more.'

On page 5, line 4, after the word "equal," strike out the word "quarterly" and insert the word "semiannual."

On page 5, line 5, after the word "January," strike out the comma and the word "April" and the comma, and insert the wor"d "and"; and after the word "July" strike out the comma and the words "and October."

On page 6, line 22, after the word "the," strike out the word "next"; and after the word "Congress" strike out the comma and insert the following: "next succeeding a session of the lecistature of any State from which a certificate has been withheld." 


































































